\title{
Season, equipment, and job function related to gastrointestinal problems in waste collectors
}

\author{
Ulla Irene Ivens, Niels Ebbehøj, Otto M Poulsen, Torsten Skov
}

\begin{abstract}
Objectives-Informal reports have suggested that work as a waste collector entails exposures that cause gastrointestinal symptoms-such as nausea and diarrhoea. This study explores this hypothesis by correlating data on the type of waste collected, the persons' job function, the equipment used, and the times of the week and the year of reported nausea and diarrhoea.
\end{abstract}

Methods-1747 male waste collectors and a control group for comparison of 1111 male municipality workers answered a questionnaire on work environment, work related exposure, and health status.

Results-In a multivariate analysis collection of organic and residual waste (prevalence proportion ratio (PPR) 1.45) and mixed household waste (PPR 1.43) were associated with reported nausea and so was the job loader (PPR 1.51). More symptoms were reported in the summer. Multivariate analysis of diarrhoea showed that the job front runner was associated with reported diarrhoea (PPR 1.22) and so was the job loader (PPR 1.26). More symptoms occurred in the summer. The workers stated that the gastrointestinal symptoms were related to the smell of rotten waste. This may support the hypothesis that microbial compounds were the causal agents.

Conclusion-The gastrointestinal symptoms were associated with the job of waste collector and moreover the symptoms predominantly occurred in the summer.

(Occup Environ Med 1997;54:861-867)

Keywords: gastrointestinal symptoms, occupational epidemiology, occupational exposure

Several western governments have decided that a substantial proportion of domestic waste is to be recycled. ${ }^{1}$ The introduction of recycling may involve separation in the household-for example, into a fraction of organic waste (for composting or biogas production), a fraction of combustible waste (for energy production), fractions of paper and of glass (for recycling), and a residual fraction. Collection of several waste fractions may prolong the collection interval from once a week to every second week or less often, creating favourable conditions for growth of microorganisms-such as Gram negative bacteria $-{ }^{2}$ and thereby formation of endotoxins ${ }^{3}$ which may be a cause of gastrointestinal symptoms. ${ }^{4}$

Previous informal reports state that there has been a high frequency of gastrointestinal problems among waste collectors, ${ }^{5}$ especially in the warm season and when collecting the organic fraction of the household waste. ${ }^{6}$ However, at present only scant information is available. ${ }^{1}$ Several reports exist on the relation between health and handling of waste, but most of these include workers at waste disposal ${ }^{7}$ or recycling plants. $^{8}$

Gastrointestinal problems such as diarrhoea and nausea are well known problems among occupational groups exposed to high concentrations of airborne Gram negative bacteria. This is especially the case among sewage workers and employees at compost plants. ${ }^{4910}$

The present study examines the gastrointestinal problems among waste collectors and relates reports of nausea and diarrhoea to the type of waste collected, the persons' job, the equipment used, and the times of the week and the year.

\section{Material and methods}

The study was carried out as a questionnaire based survey in 1994 among all waste collectors in Denmark. On inquiry to all municipalities in Denmark, the total number of waste collection companies (private and public) were identified, and each company was asked for information about their employed waste collectors. The response rate among the companies was $94 \%$. A total of 2412 waste collectors were identified from the company records, and a questionnaire was posted to them. Two reminders were sent and a telephone interview was also conducted among those who had not replied to the posted questionnaire. ${ }^{11}$ The data from the self administrated questionnaire and from the telephone interview were pooled according to a validation study that was carried out. ${ }^{12} \mathrm{~A}$ total of 109 waste collectors no longer worked as waste collectors because of retirement, illness, or unemployment. They were excluded. The questionnaire was answered by $75.9 \% \quad(n=1747)$ of the remaining 2303 people. The rate of refusal was $10.7 \%$, of whom $4 \%$ agreed to answer a very short questionnaire, and $13.4 \%$ did not respond at all (table 1).

The questionnaire was also sent to a control group which consisted of 1460 municipal workers, who worked mainly outdoors (road workers and park workers). These were assumed to be similar to the waste collectors for background variables as age, sex, and social 
Table 1 Response rates in the study of gastrointestinal symptoms among waste collectors

\begin{tabular}{|c|c|c|c|c|}
\hline & \multicolumn{2}{|c|}{ Waste collectors } & \multicolumn{2}{|c|}{ Comparison group } \\
\hline & Total & $\%$ & Total & $\%$ \\
\hline Original number of potential participants & 2412 & & 1460 & \\
\hline \multirow{2}{*}{\multicolumn{5}{|c|}{$\begin{array}{l}\text { Participants after subtraction of people who had died, changed job, } \\
\text { were retired, ill, or unemployed }\end{array}$}} \\
\hline & & & 1430 & 100 \\
\hline Total of returned self administrated questionnaires & 1567 & 68.1 & 1111 & 76.7 \\
\hline Telephone interviews & 180 & 7.8 & 58 & 4.0 \\
\hline Total answers & 1747 & 75.9 & 1169 & 81.7 \\
\hline People without a telephone and who did not fill in the questionnaire & 182 & 7.9 & 55 & 3.8 \\
\hline \multirow{2}{*}{\multicolumn{5}{|c|}{ People who could not be reached (wrong number/address, not at }} \\
\hline & 127 & 5.5 & 44 & 3.1 \\
\hline People who refused ${ }^{\star}$ & 247 & 10.7 & 162 & 11.3 \\
\hline Total with answers lacking & 556 & 24.1 & 261 & 18.3 \\
\hline
\end{tabular}

*Some of these people participated in the small drop out study.

status. Thirty of these people stated that they did not work any more because they had retired, were ill, or unemployed. These people were excluded. The questionnaire was answered by $81.7 \%$ of the remaining 1430 people. The rate of refusal was $11.3 \%$ but $4.5 \%$ of these agreed to answer a very short questionnaire and $6.9 \%$ did not respond at all (table 1).

The 11 female waste collectors and 32 women in the control group were excluded from the analyses because of small numbers.

The study was approved by the Danish Scientific Ethics Committee.

\section{THE QUESTIONNAIRE}

The questionnaire focused on present and past work environment, work related exposures, the psychosocial work environment, background information, and health status.

\section{Questions about exposure}

Present work conditions of importance in the waste collector working environment dealt with type of waste collected, type of container, job function, and shifts between job functions.

The types of waste were: organic waste (the wet, green part of household waste, separated by the household); mixed household waste (a non-separated fraction); the residual fraction (the dry fraction remaining when the organic part of the waste has been separated); paper (separated by the household); glass (separated by the household); and garden waste (an organic fraction separated by the household).

The types of containers were: sacks made of paper or plastic; bins without wheels (closed containers made of plastic); divided or nondivided containers with two wheels (closed containers made of plastic); containers with four wheels (huge closed containers made of plastic)

The jobs were: driver; front runner (runs in front of the truck and drags the waste containers to the road); loader (takes the container at the roadside and empties it up into the truck).

Shifts between various jobs could take place during the day, from day to day, from week to week, from month to month, or never.

Many waste collectors collect different waste fractions. A correlation analysis showed high correlations $(\rho>0.5)$ between collection of the organic waste and the residual fraction, and between paper, glass, and garden waste. Thus the types of waste were grouped into three waste fractions: (a) organic waste and the residual fraction, (b) mixed household waste, and $(c)$ paper, glass, and garden waste.

The questions about the amount of time the waste collectors were working with different fractions of waste, type of containers, and jobs were grouped so that the answers "almost all day", "about $3 / 4$ of the time", "about $1 / 2$ of the time", and "about $1 / 4$ of the time" were deemed to be "exposure" whereas "seldom or very little" and "never" were deemed to be "non-exposure".

Exposure to the combined fraction of organic waste and the residual fraction was defined as exposed (depending upon criteria already mentioned) to either one of the fractions or to both. This was also true for the combined fraction of paper, glass, and garden waste.

Twenty people answered almost all day to all the questions about how long during a day they worked with various waste fractions, and 66 people answered almost all day to the questions about how long they worked at various jobs. Three people were in both groups. As this indicated that the questionnaire was not filled in correctly these 83 people were excluded from the analyses.

In the cases of respondents who did not indicate the amount of time spent working with specific waste fractions they were recoded as the answer never, and the control group was regarded as non-exposed.

The exposure questions were based on those from the MUSIC study. ${ }^{13}$ The psychosocial questions were from the Whitehall studies ${ }^{14}$ which relates to the demand-control-support model. ${ }^{15}$ From these questions the three psychosocial exposure measures, demand, control, and job-support were calculated ${ }^{16}$ (M Marmot, personal communication, 1993).

\section{Questions on health outcome}

The questions on health status included questions on nausea ("do you sometimes have nausea?") vomiting, and diarrhoea ("do you sometimes have diarrhoea?") However, only the symptoms nausea and diarrhoea were analysed further. For each symptom additional questions were asked about the weekly and seasonal occurrence, and whether anything at work provoked the symptoms.

The answers were dichotomised, ${ }^{12}$ so that the answers no, never, and yes, sometimes a year were coded as no and the answers yes 
Table 2 Background variables age, height, weight and average daily alcohol consumption in the study of gastrointestinal symptoms among waste collectors

\begin{tabular}{|c|c|c|c|c|c|c|}
\hline & \multicolumn{3}{|c|}{ Waste collectors } & \multicolumn{3}{|c|}{ Comparison group } \\
\hline & Mean & $95 \% C I$ & Range & Mean & $95 \% C I$ & Range \\
\hline Age $(y)$ & 39 & 38.9 to 39.9 & $19-70$ & 43 & 42.2 to 43.7 & $18-70$ \\
\hline Height $(\mathrm{cm})$ & 179 & 178.6 to 179.3 & $156-206$ & 177 & 176.4 to 177.5 & $151-205$ \\
\hline Weight (kg) & 84 & 83.3 to 84.6 & 49-196 & 83 & 82.2 to 83.8 & $50-174$ \\
\hline $\begin{array}{l}\text { Daily alcohol consumption } \\
\text { (drinks) }\end{array}$ & 2.3 & 2.2 to 2.4 & $0-22$ & 2.0 & 1.8 to 2.1 & $0-16$ \\
\hline Seniority (y/months) & $9 / 3$ & $8 / 11$ to $9 / 7$ & $0 / 0-42 / 0$ & $13 / 1$ & $12 / 6$ to $13 / 7$ & $0 / 1-42 / 0$ \\
\hline
\end{tabular}

Numbers given as mean value with $95 \%$ CIs and range.

Table 3 Prevalence of background variables by symptom status in the study of gastrointestinal symptoms among waste collectors

\begin{tabular}{|c|c|c|c|c|c|c|c|}
\hline \multirow[b]{2}{*}{ Variable } & & \multicolumn{3}{|c|}{ Nausea $(n(\%))$} & \multicolumn{3}{|c|}{ Diarrhoea (n (\%)) } \\
\hline & & Yes & No & Pvalue* & Yes & No & Pvalue * \\
\hline $\begin{array}{l}\text { Migraine } \\
\text { Alcohol }\end{array}$ & $\geqslant 8$ days a year & $24(9.8)$ & $78(3.4)$ & $<0.001$ & $23(6.1)$ & $78(3.7)$ & 0.03 \\
\hline consumption & $\geqslant 5$ drinks a day & $8(3.5)$ & $21(1.0)$ & $<0.001$ & $8(2.2)$ & $21(1.0)$ & 0.05 \\
\hline Demand & Above mean & $132(54.1)$ & $938(41.1)$ & $<0.001$ & $218(57.5)$ & $851(39.8)$ & $<0.001$ \\
\hline Support & Below mean & $131(53.7)$ & $1006(44.1)$ & 0.004 & $199(52.5)$ & $934(43.7)$ & 0.002 \\
\hline
\end{tabular}

${ }^{\star} \chi^{2}$ Test for difference between the groups.

sometimes a month, yes sometimes a week, and yes daily were coded as yes.

Questions on background information included questions about sex, age, seniority, and alcohol consumption. For these questions missing values were not recoded.

\section{STATISTICAL ANALYSIS}

Logistic regression models were fitted with Proc Logistic in SAS. As explanatory variables were used variables which, according to informal reports, were assumed to influence gastrointestinal problems, and variables almost significant $(P<0.10)$ in cross tabulations. The explanatory variables included migraine more than eight days a year, and average alcohol consumption a day calculated as the total amount of beer, wine, and spirits, but not age and seniority.

All explanatory variables were included in the first model. Then the model was reduced depending upon the Wald test, and the relevance of the biological variables. If removal of one variable led to a $10 \%$ change in one or several other parameter estimates of relevant explanatory variables, the variable was maintained in the model no matter what the $P$ value.

Three models were analysed. Firstly, the waste collectors and the control group were compared regardless of the jobs of the waste collectors. Secondly, the variation of frequency of reported gastrointestinal problems according to waste fraction collected was examined. The control group consisted of non-exposed waste collectors. Mutual confounding between the waste fractions was controlled by maintaining the three waste fractions in the model even though the criteria already mentioned for inclusion were not fulfilled. Thirdly, we examined whether the frequency of reported gastrointestinal problems among waste collectors varied according to job. This model was corrected for mutual confounding between the jobs by maintaining the three job functions in the model regardless of the inclusion criteria.

The fit of the final model was analysed with the Hosmer-Lemeshow test ${ }^{17}$ and with the area under the ROC curve. ${ }^{18}$ The HosmerLemeshow test is a $\chi^{2}$ test for departure from a perfect fit, so that a $P$ value $>0.05$ means that the statistical test used did not detect significant departure from perfect fit. The area under the ROC curve is a measure of discrimination. As a general rule: area $\mathrm{ROC}=0.5$ indicates no discrimination, $\mathrm{ROC} \geqslant 0.7$ indicates acceptable discrimination, ROC $\geqslant 0.8$ indicates excellent discrimination, ROC $\geqslant 0.9$ indicates outstanding discrimination. As there can be perfect discrimination in a model with a poor fit, this analysis of the area under the ROC curve is a supplement and not a substitute for the test for fit already mentioned.

Finally the risk estimates were fitted with a general modelling procedure (Proc Genmod in SAS) with binomial error and a log link function. This analysis yields as a result the prevalence proportion ratio (PPR). ${ }^{19} 20$ For each PPR a $95 \%$ confidence interval $(95 \% \mathrm{CI})$ and $P$ value for level of significance (Wald test) are shown.

To test whether there were more symptoms in the summer time than the other seasons (autumn, winter) the proportions reporting symptoms in a specific season were compared two and two. The test was regarded as a comparison of unpaired individuals. ${ }^{21}$ A similar analysis was made for the relation between season and job.

Similarly, we tested if there were more symptoms after a weekend than during the rest of the week (midweek, end of working week, during weekends). We also tested whether exposed or

Table 4 Prevalence proportion ratios of gastrointestinal symptoms in the study of gastrointestinal symptoms among waste collectors

\begin{tabular}{ll}
\hline Symptom & $P P R(95 \% C I)$ \\
\hline Nausea & $1.40(1.08 \text { to } 1.81)^{\star}$ \\
Diarrhoea & $1.76(1.37$ to 2.28$) \dagger$ \\
\hline
\end{tabular}

${ }^{\star}$ Corrected for the psychosocial exposure measures, migraine and daily alcohol consumption.

†Corrected for the psychosocial exposure measures. 
Table 5 Final model for gastrointestinal symptoms with collected waste fraction included in the model in the study of gastrointestinal symptoms among waste collectors

\begin{tabular}{|c|c|c|c|c|}
\hline & \multicolumn{2}{|l|}{ Nausea } & \multicolumn{2}{|l|}{ Diarrhoea } \\
\hline & PPR (95\% CI) & P value & $P P R(95 \% C I)$ & $P$ value \\
\hline $\begin{array}{l}\text { Organic }+ \text { residual } \\
\text { Not exposed to organic }+ \text { residual fraction }\end{array}$ & $\begin{array}{l}1.45(1.06 \text { to } 1.98) \\
1\end{array}$ & 0.02 & $\begin{array}{l}1.07(0.84 \text { to } 1.37) \\
1\end{array}$ & 0.56 \\
\hline $\begin{array}{l}\text { Mixed household } \\
\text { Not exposed to mixed household waste }\end{array}$ & $\begin{array}{l}1.43(0.95 \text { to } 2.16) \\
1\end{array}$ & 0.09 & $\begin{array}{l}1.21(0.89 \text { to } 1.66) \\
1\end{array}$ & 0.22 \\
\hline $\begin{array}{l}\text { Paper, glass, garden } \\
\text { Not exposed to paper/glass/garden fraction }\end{array}$ & $\begin{array}{l}1.05(0.76 \text { to } 1.45) \\
1\end{array}$ & 0.76 & $\begin{array}{l}0.84(0.65 \text { to } 1.08) \\
1\end{array}$ & 0.17 \\
\hline $\begin{array}{l}\text { Migraine ( } \geqslant 8 \text { days/y) } \\
\text { Migraine }(<8 \text { days/y) }\end{array}$ & $\begin{array}{l}2.61(1.71 \text { to } 3.99) \\
1\end{array}$ & $<0.001$ & - & \\
\hline $\begin{array}{l}\text { Alcohol consumption ( } \geqslant 5 \text { drinks/day) } \\
\text { Alcohol consumption ( }<5 \text { drinks/day) }\end{array}$ & $\begin{array}{l}2.23(1.57 \text { to } 3.17) \\
1\end{array}$ & $<0.001$ & $\overline{-}$ & \\
\hline $\begin{array}{l}\text { Shift in job function (from day to day) } \\
\text { Shift in job function (week/month) } \\
\text { No shift in job function }\end{array}$ & 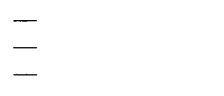 & & $\begin{array}{l}1.06(0.83 \text { to } 1.35) \\
1.58(1.20 \text { to } 2.08) \\
1\end{array}$ & $\begin{array}{l}0.64 \\
0.001\end{array}$ \\
\hline $\begin{array}{l}\text { Demand above mean } \\
\text { Demand below mean }\end{array}$ & $\begin{array}{l}1.51(1.12 \text { to } 2.03) \\
1\end{array}$ & 0.007 & $\begin{array}{l}1.94(1.56 \text { to } 2.40) \\
1\end{array}$ & $<0.001$ \\
\hline $\begin{array}{l}\text { Support below mean } \\
\text { Support above mean }\end{array}$ & $\begin{array}{l}1.20(0.89 \text { to } 1.61) \\
1\end{array}$ & 0.22 & $\begin{array}{l}1.18(0.96 \text { to } 1.45) \\
1\end{array}$ & 0.12 \\
\hline
\end{tabular}

In the analysis of nausea, 1408 were entered into the model, of these 153 had symptoms. In the analysis of diarrhoea, 1467 were entered into the model, of these 275 had symptoms.

the non-exposed workers reported more symptoms after a weekend and in the summer.

\section{Results}

Table 2 shows background information such as age, height, weight, alcohol consumption, and seniority among the waste collectors and the control group. Table 3 shows the results from the cross tabulations.

As already described, only two gastrointestinal symptoms were considered-namely, nausea and diarrhoea. For nausea 2460 people were included in the first model. Altogether 159 exposed $(12 \%)$ and $85(7 \%)$ unexposed workers $(P<0.001)$ reported nausea at some time each month or more often (PPR 1.40, $95 \%$ CI 1.08 to 1.81 ). In the analysis of diarrhoea, 2579 were included in the first model. Altogether 262 exposed (19\%) and 117 $(10 \%)$ unexposed workers $(\mathrm{P}<0.001)$ reported diarrhoea at some time each month or more often (PPR 1.76, 95\% CI 1.37 to 2.28 , table 4 )

NAUSEA

Model with waste fraction

Table 5 shows the estimated PPRs for nausea among waste collectors by type of collected waste. The model is corrected for migraine more than eight days a year, average alcohol consumption of more than five drinks a day, and the psychosocial exposure measurements job demands and job support. The HosmerLemeshow test for goodness of fit had a value of $\mathrm{P}=0.85$ and the area under the ROC curve amounted to 0.7 .

Waste collectors exposed to the organic and residual fractions (PPR 1.45, 95\% CI 1.06 to 1.98 ) and also to the fraction of mixed household waste (PPR 1.43, 95\% CI 0.95 to 2.16 ) reported nausea more often than those not exposed (table 5). Also, collectors with high demands at work (PPR 1.51, 95\% CI 1.12 to 2.03 ) and low job support (PPR 1.20, 95\% CI
0.89 to 1.61 ) reported more nausea. Few symptoms were reported among waste collectors collecting the fraction of paper, glass, and garden waste.

\section{Model with job functions}

Table 6 shows the estimated PPRs for reporting nausea for job functions, migraine status, alcohol consumption, collection of waste in non-divided containers, and the psychosocial exposure measures job demands and job support. In the test for goodness of fit $\mathrm{P}=0.52$ and the area under the ROC curve was 0.7.

Being a driver seemed to be associated with very few symptoms of nausea (PPR 0.74, 95\% CI 0.54 to 1.00 ) whereas the job loader was associated with increased reported nausea (PPR 1.51, 95\% CI 1.04 to 2.19 ). Few symptoms existed among those waste collectors who were front runners. High job demands (PPR $1.52,95 \%$ CI 1.13 to 2.04 ) and low job support (PPR 1.13, 95\% CI 0.84 to 1.52 ) were also associated with reported nausea.

Seasonal and weekly variation

Waste collectors reported more nausea in the summer time than the non-exposed control group $(\mathrm{P}<0.0001$, table 7$)$. In the summer collection of both organic waste and mixed household waste had more reported nausea than collection of other waste fractions ( $P=0.004$ and $P<0.001$, respectively). Most of the control group indicated no seasonal relation. In the exposed groups (to either a waste fraction or a job function) a decreasing frequency of nausea was reported during the rest of the year, from summer to autumn $(P<0.0001)$ and from autumn to winter $(P=0.09)$. The non-exposed workers reported more nausea in the summer than in the autumn $(P=0.03)$, and a similar amount during the autumn and winter.

As was expected more waste collectors reported nausea when returning to work after a 
Table 6 Final model for gastrointestinal symptoms with job function included in the model in the study of gastrointestinal symptoms among waste collectors

\begin{tabular}{|c|c|c|c|c|}
\hline & \multicolumn{2}{|l|}{ Nausea } & \multicolumn{2}{|l|}{ Diarrhoea } \\
\hline & $P P R(95 \% C I)$ & P value & $P P R(95 \% C I)$ & Pvalue \\
\hline $\begin{array}{l}\text { Driver } \\
\text { Not exposed as driver }\end{array}$ & $\begin{array}{l}0.74(0.54 \text { to } 1.00) \\
1\end{array}$ & 0.06 & $\begin{array}{l}0.83(0.66 \text { to } 1.03) \\
1\end{array}$ & 0.09 \\
\hline $\begin{array}{l}\text { Front runner } \\
\text { Not exposed as front runner }\end{array}$ & $\begin{array}{l}1.07(0.79 \text { to } 1.44) \\
1\end{array}$ & 0.66 & $\begin{array}{l}1.22(0.98 \text { to } 1.52) \\
1\end{array}$ & 0.07 \\
\hline $\begin{array}{l}\text { Loader } \\
\text { Not exposed as loader }\end{array}$ & $\begin{array}{l}1.51(1.04 \text { to } 2.19) \\
1\end{array}$ & 0.03 & $\begin{array}{l}1.26(0.98 \text { to } 1.62) \\
1\end{array}$ & 0.07 \\
\hline $\begin{array}{l}\text { Migraine ( } \geqslant 8 \text { days/y) } \\
\text { Migraine (<8 days/y) }\end{array}$ & $\begin{array}{l}2.85(1.89 \text { to } 4.30) \\
1\end{array}$ & $<0.001$ & - & \\
\hline $\begin{array}{l}\text { Alcohol consumption ( } \geqslant 5 \text { drinks/day) } \\
\text { Alcohol consumption ( }<5 \text { drinks/day) }\end{array}$ & $\begin{array}{l}2.08(1.47 \text { to } 2.95) \\
1\end{array}$ & $<0.001$ & - & \\
\hline $\begin{array}{l}\text { Undivided containers } \\
\text { Other types of containers }\end{array}$ & $\begin{array}{l}1.57(1.14 \text { to } 2.15) \\
1\end{array}$ & 0.005 & - & \\
\hline $\begin{array}{l}\text { Demand above mean } \\
\text { Demand below mean }\end{array}$ & $1.52(1.13$ to 2.04$)$ & 0.005 & $\begin{array}{l}1.95(1.57 \text { to } 2.42) \\
1\end{array}$ & $<0.001$ \\
\hline $\begin{array}{l}\text { Support below mean } \\
\text { Support above mean }\end{array}$ & $\begin{array}{l}1.13(0.84 \text { to } 1.52) \\
1\end{array}$ & 0.41 & $\begin{array}{l}1.20(0.98 \text { to } 1.49) \\
1\end{array}$ & 0.08 \\
\hline
\end{tabular}

In the analysis of nausea, 1408 were entered into the model, of these 153 had symptoms. In the analysis of diarrhoea, 1467 were entered into the model, of these $\mathbf{2 7 5}$ had symptoms.

weekend or holiday. The results, however, showed similar reporting among the waste collectors and the control group (table 7). More collectors of waste paper reported that nausea was unrelated to a specific weekday. Both exposed and the non-exposed workers reported a decrease in nausea over the working week (table 7).

\section{DIARRHOEA}

Model with waste fraction included

Table 5 shows the estimated PPR for reported diarrhoea for different waste fractions, changes in jobs, and the psychosocial exposure measurements job demands and job support. Testing goodness of fit with the HosmerLemeshow test gave $\mathrm{P}=0.46$ and the test for discrimination resulted in an area under the ROC curve of 0.6 . Table 5 shows that collection of mixed household waste was associated with reported diarrhoea (PPR 1.21, 95\% CI 0.89 to 1.66 ). Few symptoms were reported among those collecting organic and residual waste, paper, glass, and garden waste. High job demands (PPR 1.94, 95\% CI 1.56 to 2.40 ) and low job support (PPR 1.18, 95\% CI 0.96 to 1.45) seemed to be associated with the reported diarrhoea.

\section{Model with job functions included}

Table 6 shows the estimated PPRs for diarrhoea according to job, and the psychosocial exposure measurements job demands and job support. Testing for goodness of fit resulted in $\mathrm{P}=0.73$ and the area under the ROC curve equalled 0.6. Table 6 shows that for diarrhoea the jobs front runner (PPR 1.22, 95\% CI 0.98 to 1.52 ) and loader (PPR 1.26, 95\% CI 0.98 to 1.62) were associated with reported diarrhoea whereas the job driver seemed to be associated with fewer symptoms. Again high job demands (PPR $1.95,95 \%$ CI 1.57 to 2.42 ) and low support (PPR 1.20, 95\% CI 0.98 to 1.49 ) were also associated with reports of diarrhoea.

\section{Seasonal and weekly variation}

Diarrhoea was mostly reported among waste collectors collecting organic waste $(P=0.04)$ and mixed household waste $(P<0.001)$ compared with non-exposed waste collectors

Table 7 Prevalence and prevalence proportion of nausea symptoms by season, weekday, and type of exposure in the study of gastrointestinal symptoms among waste collectors

\begin{tabular}{|c|c|c|c|c|c|c|c|c|}
\hline \multirow[b]{2}{*}{ Symptoms } & \multicolumn{7}{|c|}{ Waste collectors } & \multirow[b]{2}{*}{$\begin{array}{l}\text { Comparison } \\
\text { group }\end{array}$} \\
\hline & $\begin{array}{l}\text { Organict } \\
\text { residual } \\
\text { fraction }\end{array}$ & $\begin{array}{l}\text { Mixed } \\
\text { household }\end{array}$ & $\begin{array}{l}\text { Paper, glass, } \\
\text { garden }\end{array}$ & Drivers & Front runner & Loader & $\begin{array}{l}\text { Undivided } \\
\text { group }\end{array}$ & \\
\hline Total & $59(15.6)$ & $139(11.8)$ & $53(12.7)$ & $107(10.5)$ & $91(12.6)$ & $126(12.2)$ & $163(11.3)$ & $81(7.5)$ \\
\hline \multicolumn{9}{|l|}{ Seasonal variation: } \\
\hline Spring & 0 & 0 & 0 & 0 & 0 & 0 & 0 & 0 \\
\hline Summer & $24(42.1)$ & $24(42.1)$ & $21(40.4)$ & $38(36.5)$ & $35(39.3)$ & $49(39.5)$ & $59(37.1)$ & $8(10.4)$ \\
\hline Autumn & $1(1.8)$ & $1(1.8)$ & 0 & $3(2.9)$ & $3(3.4)$ & $3(2.4)$ & $4(2.5)$ & $3(3.9)$ \\
\hline Winter & 0 & 0 & 0 & 0 & $1(1.1)$ & $1(0.8)$ & $1(0.6)$ & $2(2.6)$ \\
\hline All year & $32(56.1)$ & $32(56.1)$ & $31(59.6)$ & $63(60.6)$ & $50(56.2)$ & $71(57.3)$ & $95(59.8)$ & $64(87.1)$ \\
\hline \multicolumn{9}{|l|}{ Weekly variation: } \\
\hline \multicolumn{9}{|l|}{ When returning to work after } \\
\hline weekends/holidays/days off & $7(11.9)$ & $23(16.7)$ & $6(11.5)$ & $16(15.1)$ & $18(19.8)$ & $18(14.4)$ & $25(15.6)$ & $14(17.5)$ \\
\hline In the middle of the week & $5(8.5)$ & $8(5.8)$ & $1(1.9)$ & $6(5.7)$ & $5(5.5)$ & $7(5.6)$ & $8(5.0)$ & $2(2.5)$ \\
\hline At the end of the week & $3(5.1)$ & $7(5.1)$ & $2(3.9)$ & $6(5.7)$ & $3(3.3)$ & $6(4.8)$ & $8(5.0)$ & $3(3.8)$ \\
\hline In weekends/holidays/days off & 0 & $2(1.5)$ & 0 & $2(1.9)$ & $1(1.0)$ & $2(1.6)$ & $2(1.3)$ & $2(2.5)$ \\
\hline No special weekday & $44(74.6)$ & $98(71.0)$ & $43(82.7)$ & $76(71.7)$ & $64(70.3)$ & $92(73.6)$ & $117(73.1)$ & $59(73.8)$ \\
\hline
\end{tabular}

Values are rounded prevalence (prevalence proportions \%). 
Table 8 Prevalence and prevalence proportion of diarrhoea by season, weekday, and type of exposure in the study of gastrointestinal symptoms among waste collectors

\begin{tabular}{|c|c|c|c|c|c|c|c|c|}
\hline \multirow[b]{2}{*}{ Symptoms } & \multicolumn{7}{|c|}{ Waste collectors } & \multirow[b]{2}{*}{$\begin{array}{l}\text { Comparison } \\
\text { group }\end{array}$} \\
\hline & $\begin{array}{l}\text { Organict } \\
\text { residual } \\
\text { fraction }\end{array}$ & $\begin{array}{l}\text { Mixed } \\
\text { household }\end{array}$ & $\begin{array}{l}\text { Paper, glass, } \\
\text { garden }\end{array}$ & Drivers & Front runner & Loader & $\begin{array}{l}\text { Undivided } \\
\text { group }\end{array}$ & \\
\hline Total & $75(20.0)$ & $235(20.0)$ & $71(17.1)$ & $179(17.7)$ & $157(22.0)$ & $208(20.2)$ & $275(19.1)$ & $104(9.7)$ \\
\hline \multicolumn{9}{|l|}{ Seasonal variation: } \\
\hline Spring & 0 & $2(0.9)$ & 0 & $4(2.3)$ & $2(1.3)$ & $3(1.5)$ & $4(1.5)$ & 0 \\
\hline Summer & $18(24.3)$ & $56(24.8)$ & $15(21.7)$ & $21(11.8)$ & $14(9.0)$ & $21(10.2)$ & $28(10.3)$ & $11(10.7)$ \\
\hline Autumn & $2(2.7)$ & $3(1.3)$ & $3(4.4)$ & $16(9.0)$ & $11(7.1)$ & $19(9.2)$ & $22(8.1)$ & $4(3.9)$ \\
\hline Winter & $1(1.4)$ & $3(1.3)$ & 0 & $12(6.7)$ & $7(4.5)$ & $19(9.2)$ & $21(7.7)$ & 0 \\
\hline All year & $53(71.6)$ & $162(71.7)$ & $51(73.9)$ & $125(70.2)$ & $122(78.2)$ & $144(69.9)$ & $197(72.4)$ & $88(85.4)$ \\
\hline \multicolumn{9}{|l|}{ Weekly variation: } \\
\hline When returning to work after & & & & & & & & \\
\hline weekends/holidays/days off & $6(8.0)$ & $25(10.7)$ & $8(11.3)$ & $16(15.1)$ & $18(19.8)$ & $18(14.4)$ & $28(10.3)$ & $11(10.7)$ \\
\hline In the middle of the week & $6(8.0)$ & $19(8.2)$ & $5(7.0)$ & $6(5.7)$ & $5(5.5)$ & $7(5.6)$ & $22(8.1)$ & $4(3.9)$ \\
\hline At the end of the week & $8(10.7)$ & $16(6.9)$ & $5(7.0)$ & $6(5.7)$ & $3(3.3)$ & $6(4.8)$ & $21(7.7)$ & 0 \\
\hline On weekends/holidays/days off & $1(1.3)$ & $2(0.9)$ & 0 & $2(1.9)$ & $1(1.1)$ & $2(1.6)$ & $4(1.5)$ & 0 \\
\hline No special weekday & $54(72.0)$ & $171(73.4)$ & $53(74.7)$ & $76(71.7)$ & $64(70.3)$ & $92(73.6)$ & $197(72.4)$ & $88(85.4)$ \\
\hline
\end{tabular}

Values are rounded prevalence (prevalence proportions \%).

(table 8). Most of the control group did not associate the diarrhoea with a specific season. In the groups of exposed workers (exposed to either a waste fraction or a job function) less diarrhoea was reported during the rest of the year than in the summer.

As expected diarrhoea was more prevalent among waste collectors (except among those collecting the organic fraction) when returning to work after a weekend or holiday (table 8). Waste collectors of paper indicated that the diarrhoea was mostly not related to a specific weekday. Both the exposed and the nonexposed workers reported that diarrhoea decreased over the working week (table 8). More of the non-exposed than the exposed waste collectors could not relate the diarrhoea to any specific weekday.

\section{Discussion}

In this questionnaire based study it was found that waste collectors reported more gastrointestinal symptoms than did municipal workers. Moreover, people collecting the organic, residual, and mixed household waste fractions reported more nausea than the non-exposed waste collectors. Loaders reported most nausea. The prevalence of nausea was highest in the summer, followed by the autumn and winter. Nausea was reported mostly to occur when returning to work after the weekend both among waste collectors and in the control group.

Diarrhoea occurred among the people collecting mixed household waste or working as either front runner or loader. The prevalence of diarrhoea was highest in the summer among those exposed to the waste fractions organic, residual, and mixed household.

Few cases of vomiting were reported, so vomiting could not be further analysed.

The findings correspond with the results of the bioaerosol measurements made in the CORE project, ${ }^{22}$ where the lowest concentration of total microorganisms, Aspergilus fumigatus, and endotoxin in the air around the truck were found in the winter. The seasonal pattern of other endotoxins $\mathrm{s}^{22}$ followed the seasonal pattern of gastrointestinal problems. Bacterial concentrations showed no clear seasonal pattern.
Gram negative bacteria, found in high concentrations in household waste, ${ }^{10}$ contain the endotoxin in their outer cell wall. ${ }^{23}{ }^{24}$ The endotoxin is released only when the bacteria dies and disintegrates. The fact that inhaled Gram negative bacteria, which contain endotoxin, can cause inflammation of the airways ${ }^{25}$ and other health effects ${ }^{26}$ may also suggest a relation with gastrointestinal problems. ${ }^{4}$ The mean concentrations of personal exposure to airborne endotoxin during waste collection has been measured as 1-7 EU/m $\mathrm{m}^{3},{ }^{2}$ which is lower than the concentration presently considered to be hazardous to human health. Very little of the inhaled endotoxin, however, penetrates through the lung tissue into the bloodstream. ${ }^{24}$ To our knowledge there are no studies on the amounts of other inhaled microorganisms that can penetrate the bloodstream. In a study of refuse workers no clear pattern was found between gastrointestinal symptoms and exposure to endotoxin. ${ }^{8}$ It is therefore not likely that endotoxin itself is a probable causal agent for gastrointestinal symptoms, but alternatively enterotoxins, produced by several Gram negative rods, have been suggested as a more likely cause of gastrointestinal symptoms. ${ }^{4}$

People collecting the waste fractions organic, residual and mixed household waste had a significantly increased PPR for nausea, but only the collection of the mixed household waste was associated with diarrhoea. Some of the waste collectors indicated factors in their work environment, typically the smell of rotten waste, that were possible causes of the gastrointestinal symptoms. A possible explanation for the differences between waste fractions in their association with nausea and diarrhoea might be that most waste collectors collect several types of waste, and it was difficult for them in the questionnaire precisely to indicate how much time of the day was used on each specific fraction. This will give a misclassification of the exposure, and this misclassification may alter the risk estimates. It is also possible that the concentration of bacteria in the waste is high enough to cause the non-specific symptom nausea but not high enough to induce diarrhoea. 
During the working week most symptoms were reported after the weekend, which is typical for exposure to endotoxin. ${ }^{23}{ }^{25}$ This pattern occurred among both exposed and nonexposed workers, thus the symptoms were not only due to the exposures of waste collectors.

A little less than $3 \%$ of the waste collectors who reported symptoms of nausea and around $4 \%$ of those who reported diarrhoea did not indicate any seasonal or weekly pattern to their gastrointestinal symptoms. In the control group the equivalent numbers were around $6 \%$ and $7 \%$ respectively. As more people in the control group were not aware of when during a year or week their symptoms occurred, this might indicate a recall bias in the waste collector group. The size of this recall bias however, cannot be determined.

The $4 \%$ of the waste collectors and the $4.5 \%$ of the municipal workers who did not want to fill in the questionnaire but filled in the short questionnaire (about age and loin pain) did not differ from the respondents, meaning that this investigation should be representative of waste collectors. ${ }^{11}$

The analysis of the association between gastrointestinal problems and specific job tasks among waste collectors produced the same resulting pattern if the control group was included in the models. This indicates that the relation that was found in this study is strong as the comparisons were made within a group.

Migraine and high alcohol consumption are factors known to be associated with nausea. The estimated PPRs were high for people with migraine and for those drinking on average more than five drinks a day. Finding this tendency in our study indicated that the questionnaire reliably identified gastrointestinal problems.

Measures on the psychosocial work environment were included in the final models of the relation between exposure and nausea and diarrhoea. This means that the relation that still exists when psychosocial factors were included must be explained by factors other than the psychosocial factors high job demands and low job support. Thus, gastrointestinal problems among waste collectors may be reduced not only by reduction in physical exposure but also by changes in the psychosocial work environment-for example, by changes in the work organisation.

\section{Conclusion}

This study showed a causal relation between gastrointestinal problems and the job as a waste collector. Moreover more symptoms occurred during the summer.

The present study is part of the 1993-8 research programme waste collection and recycling (CORE), which is supported jointly by the Danish Ministry of the Environment and the Ministry of Labour.

1 Poulsen OM, Breum NO, Ebbehøj N, Hansen ÅM, Ivens UI, van Lelieveld $\mathrm{D}$, et al. Collection of domestic waste. Review of occupational health and their possible causes. $S c i$ Total Environ 1995;170:1-19.

2 Nielsen EM, Nielsen BH, Breum NO. Occupational bioaerosol exposure during collection of household waste. Annals of Agricultural and Environmental Medicine 1995;2:53-

3 Dutkiewicz J, Jablonski L, Olenchock S. Occupational biohazards: a review. Am $\mathcal{F}$ Ind Med 1988;14:605-23.

4 Lundholm M, Rylander R. Work related symptoms among sewage workers. Br f Ind Med 1983;40:325-9.

5 Andersen T, Petersen C, Bjørn K, Wibroe L, Ebbehøj N. Arbejdsmiljoproblemer ved indsamling af organisk husholdningsaffald (in Danish). Miljøstyrelsen, 1993.

6 Netterstrøm B. Vurdering af helbredsmassige effekter hos renovationsarbejdere ved indsamling af grent affald. AFAV. (in Danish). Arbejdsrapport 1990

7 Crook B, Welham S, Higgins S, Williamson PAM, Wilson $\mathrm{JK}$, Lacey J. Airborne microorganisms associated with domestic waste disposal: effects on the health of exposed workers. Unpublished report to the Health and Safety Executive, Contract NO 1/MS/126/643/82. Harpenden, Herts: Crop Protection Division and Statistics Units, Institute of Arable Crops Research, Rothamsted Experimental Station, 1991:1-11.

8 Sigsgaard T, Malmros P, Nersting L, Petersen C. Respiratory disorders and atopy in Danish resource recovery tory disorders and atopy in Danish resource recovery

9 Zuskin E, Mustajbegovic J, Schacter EN. Respiratory function in sewage workers. Am $\mathcal{F}$ Ind Med 1993;23:751-61.

10 Lundholm M, Rylander R. Occupational symptoms among compost workers. F Occup Med 1980;22:256-7.

11 Ivens UI, Hansen J, Skov T, Poulsen OM, Ebbehøj N. Sikkerhed og sundhed ved affald og genanvendelse. Spergeskeangelsen (Occupational Safety and Health in waste collection and recycling. The questionnaire study among waste collectors. The baseline study) (summary in English). Copenhagen, Denmark Arbejdstilsynet, 1996:1-160.

12 van Ooijen M, Ivens UI, Johansen C, Skov T. Comparison of a self-administrated questionnaire and a telephone interview of 146 Danish waste collectors. $\mathrm{Am} 7$ Ind $\mathrm{Med}$ 1997;31:653-8.

13 Wiktorin C, Karlquist L, Winkel J, Stockholm MUSIC study group. Validity of self-reported exposures to work study group. Validity of self-reported exposures to work postures and manual materials

14 Joffe $M$. Validity of exposure data derived from a structured questionnaire. Am $\mathcal{f}$ Epidemiol 1992;135:564-70.

15 Karasek R. Job demands, job decision latitude, and menta strain: implications for job redesign. Administrative Science Quarterly 1979;24:285-308.

16 Kristensen TS. The demand-control-support model: methodological challenges for future research. Stress Med 1995;11:17-26.

17 Hosmer DW, Lemeshow S. Applied logistic regression. New York: John Wiley, 1989:1-307.

18 Lemeshow S. Regression and categorical data methods. New England Epidemiology Institute Summer School, 1995.

19 Zocchetti C, Consonni D, Bertazzi PA. Estimation of prevalence rate ratios from cross-sectional data. Int $\mathcal{f}$ Epidemio 1995;24:1064-5.

20 Skov T, Deddens J, Petersen M, Endahl L. Prevalence proportion ratios: estimation and hypothesis testing. Int $\mathcal{F}$ Epidemiol 1997; (in press).

21 Armitage $P$, Berry G. Statistical methods in medical research. Oxford: Blackwell, 1987:1-559.

22 Nielsen EM, Breum NO, Nielsen BH, Midtgaard U, Poulsen OM. Bioaerosol exposure in waste collection: comparative study on the significance of collection equipment, type of waste and seasonal variation. Ann Occup Hyg 1997;41:325-44.

23 Rylander R, Bake B, Fischer J, Helander IM. Pulmonary function and symptoms after inhalation of endotoxin. $\mathrm{Am}$ Rev Respir Dis 1989;140:981-6.

24 Rylander $R$. The role of endotoxin for reactions after exposure to cotton dust. Am $\mathcal{F}$ Ind Med 1987;12:687-97.

25 Rylander $R$, Bergström $R$. Bronchial reactivity among cotton workers in relation to dust and endotoxin exposure. Am Occup Hyg 1993;37:57-63.

26 Laitinen S, Nevalainen A, Kotimaa M, Liesivuori J, Martikainen P. Relationship between bacterial counts and endotoxin concentrations in the air of wastewater treatment plants. Appl Environ Microbiol 1992;58:3774-6. 